BOTANICA

ISSN 2538-8657

2020, 26(1): 28-39

\title{
MODIFYING EFFECTS OF SOME PLANT HORMONES ON ZUCCHINI COTYLEDONS SUBJECTED TO HIGH TEMPERATURE AND EXCESS COPPER
}

\author{
Ekaterina Stoynova-Bakalova ${ }^{1}$, Natalia Ivanova ${ }^{1}$, Dimitar BaKalov ${ }^{2}$, Liliana Gigova ${ }^{1 *}$ \\ ${ }^{1}$ Bulgarian Academy of Sciences, Institute of Plant Physiology and Genetics, Acad. G. Bonchev Str. Bl. 21, 1113 \\ Sofia, Bulgaria \\ ${ }^{2}$ Medical University of Sofia, Zdrave Str. 2, Sofia BG-1431, Bulgaria \\ *Corresponding author. E-mail: gigova01@gmail.com
}

\begin{abstract}
Stoynova-Bakalova E., Ivanova N., Bakalov D., Gigova L., 2020: Modifying effects of some plant hormones on zucchini cotyledons subjected to high temperature and excess copper. - Botanica, 26(1): 28-39.

The aim of the study was to investigate the potential beneficial effects of exogenous application of methyl jasmonate (MeJa) and phenylurea cytokinin (4PU-30) on zucchini (Cucurbita pepo L.) cotyledons subjected to high temperature (HT) and combined HT plus excess copper $\left(\mathrm{Cu}^{2+}\right)$ stress. Compared to HT stressed zucchini cotyledons, exposure to excess $\mathrm{Cu}^{2+}$ prior to $\mathrm{HT}$ treatment inhibited the growth, decreased superoxide dismutase (SOD), glutathione peroxidase (GPx) and glutathione reductase (GR) activities, increased glutathione-Stransferase (GST) and peroxidase (Px) total activities, and induced new enzyme isoforms (GST4, GST8, and Px4). The effect of MeJa on the double-stressed plants was to increase SOD, GPx and Px total activities and stimulate the activity of GST8, GST9, GST10, SOD5, Px3 and Px8 isoenzymes. In addition to SOD, GPx and Px, 4PU-30 increased GST total activity, up-regulated Px1 and GR1, and had a higher stimulatory effect on SOD5, Px3, GPx3, GST9 and GST10 activities. Copper, 4PU-30 and MeJa treatments changed the abundance and pattern (MeJa) of soluble zucchini polypeptides in a specific manner. MeJa and especially 4PU-30 applied alone, or in combination, stimulated the growth of later HT-treated cotyledons. 4PU-30 counteracted better than MeJa in the HT+heavy metal-caused inhibition of the growth. The data indicated that both MeJa and 4PU30 may protect the zucchini plants from high temperature and combined high temperature plus excess copper stress, but 4PU-30 was more effective; the protective effect was related to the changes in the gene expression, total antioxidant enzyme activities and the activity of individual isoforms of the enzymes.
\end{abstract}

Keywords: antioxidant enzymes, enzyme isoforms, growth, heavy metal, high-temperature, jasmonate, oxidative stress, phenylurea cytokinin.

\section{INTRODUCTION}

Abiotic stresses such as high temperature (HT) and heavy metal stress are among the major factors that negatively affect plant growth, development, physiological processes, and productivity (KUMAR et al., 2012; HasanuZZAMAn et al., 2013). Unfavourable environmental conditions disturb the delicate cellular redox balance leading to a significant accumulation of reactive oxygen species (ROS). Although ROS can function as useful signalling molecules, when are overproduced they can cause inactivation of enzymes, protein degradation, lipid peroxidation, and damage to DNA (Suzuki \& MitTler, 2006; Zhu et al., 2013). To eliminate or reduce harmful effects of increased ROS levels, the plants are known to develop enzymatic and nonenzymatic detoxification mechanisms (Sharma et al., 2012). The importance of antioxidant enzymes (AOE) is in their ability to scavenge ROS and, thereby, prevent oxidative damage. Superoxide radicals are converted to $\mathrm{H}_{2} \mathrm{O}_{2}$ by the action of SOD, and the accumulation of $\mathrm{H}_{2} \mathrm{O}_{2}$ is prevented by the ac- 
tivities of catalase (CAT), Px and GR. High activities of AOE in two heat-tolerant squash (Cucurbitaceae) genotypes have been found in response to heat stress (ArA et al., 2013), and they may have a general role in the acquisition of plant tolerance to different environmental stresses. Studies on heat-acclimated and non-acclimated turfgrass species under heat stress have indicated that the former has a lower ROS content as a result of enhanced synthesis of ascorbate and glutathione (Xu et al., 2006). Significant increase in the activity of all studied enzymes - SOD, CAT, ascorbate peroxidase (APx) and guaiacol peroxidase in Mentha pulegium has been registered under excess $\mathrm{Cu}^{2+}$ conditions (CANDAN \& TARHAN, 2003). However, in Brassica junicea seedlings, $\mathrm{Cu}^{2+}$ treatment causes increase in the activities of Px, APx, SOD, but induces a decrease in the activity of CAT (WANG et al., 2004).

Environmental stresses induce the synthesis of different plant hormones. Phytohormones such as jasmonates, abscisic acid, indole-3-acetic acid, cytokinins, auxins, gibberellins, salicylic acid, and the crosstalks between them, are crucial for the growth and development of plants and also in mediating various stress responses (Verma et al., 2016; SERGIEV et al., 2017; Per et al., 2018; Sytar et al., 2019). The exogenous application of phytohormones has been observed to mitigate the HT stress-induced damage in plants and alleviate the toxic impact of heavy metals. For example, heating of a wild-type Arabidopsis thaliana leads to the accumulation of a range of jasmonates, and exogenous application of MeJa protects this plant from heat stress (CLARKE et al., 2009). Jasmonic acid (JA, $50 \mu \mathrm{M}$ ) is able to extenuate the negative changes in grape seedlings caused by heat stress $\left(42^{\circ} \mathrm{C}\right)$. This protection is accompanied by the upregulation of antioxidant enzyme activities (SOD, CAT and Px) compared to these in heated but JA-untreated seedlings (CHEN et al., 2006). The cadmium (Cd)-stressed rice seedlings exposed to MeJa reveal consistent improvement in the CAT, SOD, Px and GR responses along with glutathione pools, which perhaps lowers the Cd-induced oxidative injury (Singh \& SнAн, 2014). The application of the phenylurea cytokinin 4PU-30 to Phaseolus vulgaris plants subjected to high temperature (YORDANOv et al., 1997) and to maize seedlings under drought (ToDOROv et al., 1998) and herbicide glyphosate action
(Sergiev et al., 2006), not only enhances the plant growth, but also improves the stress tolerance.

The impact of MeJa and 4PU-30, applied alone and in combination, on the growth, gene expression and antioxidant enzyme activity has presently been studied using cultivated zucchini cotyledons. As in nature plants are often exposed to complex environmental perturbations, and to our knowledge, the role of cytokinin and jasmonates in HT tolerance under multiple stress conditions has not been investigated to date, we analysed the effect of plant hormones on the thermotolerance under double stress conditions provided by additional $\mathrm{Cu}^{2+}$ treatment. Copper was used because this micronutrient plays an essential role in photosynthesis, respiration, antioxidant activity, cell wall metabolism and hormone perception, but in excess, it causes severe phytotoxic and oxidative damage (YRUELA, 2009). It was hypothesized that exogenous application of 4PU-30 or/and MeJa may enhance the plant defense responses against harmful ROS induced by HT and heavy metal stress.

\section{MATERIALS AND METHODS}

\section{Plant material and treatments}

Seeds of one fruit of Cucurbita pepo L., cv. Cocozelle var. Tripolis (zucchini) were stripped of their seed coats, and cotyledons isolated from the embryonic axes of the seed were placed in covered Petri dishes on filter paper soaked with distilled water (reference sample) or with water supplemented with either $\mathrm{Cu}$ $\mathrm{SO}_{4}\left(\mathrm{Cu}^{2+}, 1000 \mu \mathrm{M}\right)$, phenylurea cytokinin $(10 \mu \mathrm{M})$, MeJa $(100 \mu \mathrm{M})$, and combinations thereof. We used such a high concentration of $\mathrm{Cu}^{2+}$ to obtain evident growth inhibition after five days. The cotyledons were cultivated in a growth chamber at $28^{\circ} \mathrm{C}$ in the light (16:8 $\mathrm{h}$ light-dark photoperiod with irradiance of 60$80 \mu \mathrm{mol} \mathrm{m} \mathrm{m}^{-2} \mathrm{~s}^{-1}$ provided by daylight fluorescent tubes). After 5-day cultivation, the zucchini cotyledons were transferred to $45^{\circ} \mathrm{C}$ for the next $24 \mathrm{~h}$.

\section{Chemicals}

Phenylurea cytokinin $N^{1}$-(2-chloro-4-pyridyl)- $N^{2}$ phenylurea (4PU-30) was kindly provided by Prof. K. Shudo, University of Tokyo, Japan; methyl jasmonate was obtained from Serva (Heidelberg, Germany). All chemicals used in the enzyme activity assays were purchased from either Sigma Chemicals 
(St Louis, MO) or Merck KGaA (Darmstadt, Germany). Protein molecular weight marker was from Fermentas (Burlington, Ontario, Canada).

\section{Growth analysis}

The growth of zucchini cotyledons was analysed by an increase in their area. For this, the cotyledons were carefully flattened and scanned (Epson Perfection 2480 Photo scanner, Matsumoto-shi City, Japan). The area of the cotyledons was measured using 3DDoctor software (Able Software Corp., Lexington, MA, USA).

\section{Statistics}

All experiments were repeated three times. The area of 20 zucchini cotyledons for each treatment was measured. The data reported are mean values $\pm \mathrm{SD}$. The differences between the treatment groups were statistically analysed using one-way ANOVA followed by the Tukey post hoc test.

Protein extraction and analysis by polyacrylamide gel electrophoresis in the presence of SDS (SDS-PAGE)

The zucchini cotyledons were ground with quartz sand in cold extraction buffer $(60 \mathrm{mM}$ Tris- $\mathrm{HCl}$, $\mathrm{pH}$ 6.8, containing $5 \mathrm{mM}$ EDTA and $14 \mathrm{mM}$ 2-mercaptoethanol), in a pre-cooled mortar and pestle. The homogenates were centrifuged at $13000 \times \mathrm{g}$ for $20 \mathrm{~min}$. The soluble protein in the supernatant was analysed by SDS-PAGE. To identify changes in the protein content and polypeptide pattern among the treatments, equal volumes of the samples, extracted from equal fresh weights of cotyledons, were loaded. SDS-PAGE was performed as described by OKAJIMA et al. (1993), using $5 \%$ and $12 \%$ polyacrylamide in the stacking and resolving gels, respectively. Polypeptides were detected by Coomassie Blue staining and the differences in the band number and intensity (quantity) of the respective bands were estimated by image analysis of the gels with Gel-Pro Analyzer 3.2 software (Media Cybernetics Inc., Bethesda, MD USA).

\section{Native PAGE and antioxidant enzyme activity staining}

Equal amounts $(20 \mu \mathrm{g})$ of protein from the zucchini cotyledons exposed to different treatments were subjected to discontinuous PAGE under nondenaturing, nonreducing conditions essentially as described by ОкалIмA et al. (1993), but in the absence of SDS. The protein concentration was measured by the dye-binding assay (BRADFORD, 1976) with bovine serum albumin grade V as a standard. Electrophoretic separation was performed on $10 \%$ polyacrylamide gels for 3-4 h with a constant current of $35 \mathrm{~mA}$ per gel. Upon completion of electrophoresis, separate gels were stained for the activities of SOD (EC 1.15.1.1), diaminobenzidine-specific peroxidase (Px, EC 1.11.1.7), GPx (EC 1.11.1.9), GST (EC 2.5.1.18) and GR (EC 1.6.4.2).

The methods of AzEVEDo et al. (1998), ANDERSON et al. (1995) and Rojas-Beltran et al. (2000) were used for in gel activity staining of SOD (including identification of its metaloforms), GR and Px, respectively, as has been detailed in our previous paper (GIGOVA et al., 2012). Briefly, in order to visualize the bands of SOD isoforms, the gels were soaked in $0.1 \mathrm{mM}$ nitroblue tetrazolium (NBT), $0.05 \mathrm{mM}$ riboflavin, and $0.3 \%$ $(\mathrm{v} / \mathrm{v})$ tetramethyl ethylenediamine in $50 \mathrm{mM}$ potassium phosphate buffer (PPB, $\mathrm{pH} 7.8$ ) for $20 \mathrm{~min}$ in the dark and subsequently illuminated in a light box. After about $15 \mathrm{~min}$, SOD isoforms appeared as achromatic bands on a blue background. The different SOD metaloforms were identified by preincubation of parallel gels with selective inhibitors $(2 \mathrm{mM}$ potassium cyanide to inhibit $\mathrm{Cu} / \mathrm{ZnSOD}$ and $5 \mathrm{mM} \mathrm{H} \mathrm{O}_{2}$ to inhibit both $\mathrm{Cu} / \mathrm{ZnSOD}$ and FeSOD).

The staining solution for GR activity consisted of $0.24 \mathrm{mM} 3$-(4,5-dimethyl-2-thiazolyl)-2,5-diphenyl2H-tetrazolium bromide (MTT), $0.34 \mathrm{mM}$ 2,6-dichlorophenolindophenol, $3.6 \mathrm{mM}$ oxidized glutathione (GSSG), and $0.4 \mathrm{mM}$ reduced form of nicotinamide adenine dinucleotide phosphate (NADPH) in $250 \mathrm{mM}$ Tris-HCl buffer ( $\mathrm{pH}$ 7.8). GR isoforms were detected by incubating the gels in this solution for $1 \mathrm{~h}$ in the dark.

The bands of Px isoforms were localized on the gel by staining in $50 \mathrm{mM}$ PPB (pH 7.0) containing $0.5 \mathrm{mg} / \mathrm{ml}$ of diaminobenzidine (DAB) and $5 \mathrm{mM}$ of $\mathrm{H}_{2} \mathrm{O}_{2}$ until brown bands on an uncoloured background appeared.

Staining for GPx was achieved as described by Lin et al. (2002). The gels were washed in distilled water and soaked in the substrate solution, containing $50 \mathrm{mM}$ Tris- $\mathrm{HCl}$ buffer, $\mathrm{pH}$ 7.9, $13 \mathrm{mM}$ glutathione 
(GSH), and $0.004 \% \mathrm{H}_{2} \mathrm{O}_{2}$, with gentle shaking for 10-20 min. After a brief rinse, the GPx isoenzymes were detected by incubating the gels in darkness with 1.2 mM MTT and $1.6 \mathrm{mM}$ phenazine methosulphate (PMS) in distilled water until clear bands appeared on a purple background.

The gel was stained for GST activity using the method of Ricci et al. (1984). Briefly, after electrophoretic run, the gel was equilibrated in $100 \mathrm{mM} \mathrm{PPB}$, pH 6.5 for $10 \mathrm{~min}$, and transferred to a reaction mixture containing $4.5 \mathrm{mM} \mathrm{GSH}, 1 \mathrm{mM}$ 1-chloro-2,4dinitrobenzene (CDNB), and $1 \mathrm{mM} \mathrm{NBT}$, dissolved in the same PPB at $37^{\circ} \mathrm{C}$ for $10 \mathrm{~min}$. Further, the gel was incubated at room temperature in $100 \mathrm{mM}$ Tris$\mathrm{HCl}$ buffer, $\mathrm{pH}$ 9.6, supplied with $3 \mathrm{mM}$ PMS. The activity bands appeared as achromatic zones against a blue background.

Gel patterns were photographed immediately after staining using the UVItec gel documentation system (Cambridge, UK) and the images were analysed using Gel-Pro32 Analyzer software (Media Cybernetics, Bethesda, MD USA). The intensity (activity) of each band (isoenzyme) resolved was measured as total integrated optical density (IOD), in arbitrary units (a. u.). As each enzyme had multiple bands, the sum of their IOD values was considered as total enzyme activity for a particular treatment. The experiments were repeated at least three times. The absolute values for the IOD of each isoform varied between the experiments, but near-identical trends in each activity were clearly identified. Quantitative data for the activity of each enzyme were, therefore, presented from a single representative experiment.

\section{RESULTS AND DISCUSSION}

\section{Cotyledon growth}

$\mathrm{Cu}^{2+}(1000 \mu \mathrm{M})$ enhanced the known inhibitory effect of HT on zucchini cotyledon growth. Phenylurea cytokinin (4PU-30, $10 \mu \mathrm{M}$ ) significantly stimulated the enlargement of HT-stressed cotyledons and counteracted better than MeJa in the heavy metal + HT-caused inhibition of the growth (Fig. 1). Recently, we have found that 4PU-30 is a strong stimulator of cell growth in zucchini (STOYNOVA-BAKALOva et al., 2008; Stoynova-BAKALOva et al., 2009) and this effect is maintained after application of excess $\mathrm{Cu}^{2+}$ (Stoynova-Bakalova et al., 2009). The present

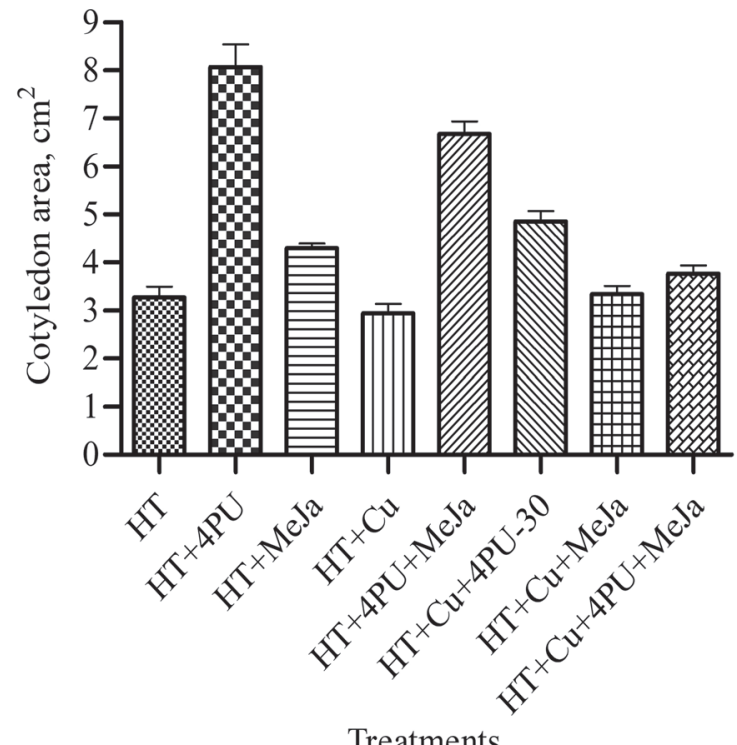

Treatments

Fig. 1. The area of zucchini cotyledons under high temperature $(\mathrm{HT})$ and high temperature plus excess copper $(\mathrm{HT}+\mathrm{Cu})$ stresses, pretreated with exogenous methyl jasmonate (MeJa), phenylurea cytokinin (4PU) and combination of both. Differences between the treatments were statistically significant, $\mathrm{F}$ $(7,152)=1078, p<0.001$, as assessed by the ANOVA and the Tukey post hoc analysis, except for HT versus $\mathrm{HT}+\mathrm{Cu}$ $+\mathrm{MeJa}$

results indicated that the growth-stimulatory effect of the cytokinin was also preserved under combined excess $\mathrm{Cu}^{2+}$ and HT stress. MeJa $(100 \mu \mathrm{M})$ applied alone significantly stimulated the enlargement of heat-treated and double-stressed zucchini cotyledons, but to a lesser extent than 4PU-30. Moreover, MeJa decreased the stimulating effect of cytokinin, especially in the presence of $\mathrm{Cu}^{2+}$. The protective effect of $5 \mu \mathrm{M}$ MeJa has previously been reported on Arabidopsis thaliana heat-stressed seedlings by reducing the electrolyte leakage, but at higher concentration $(30 \mu \mathrm{M})$, the hormone has a reverse effect (Clarke et al., 2009). Taking together, our and literature data showed that MeJa protection from HT stress is not only concentration, but also plant species dependent.

\section{Protein profiles}

The polypeptide composition and abundance of cotyledons treated for six days was compared after denaturing polyacrylamide gel electrophoresis. The 4PU-30 treatment did not change the spectrum of 
visible polypeptide bands compared to that of the untreated, heat-stressed cotyledons, but the intensity of some bands markedly increased or decreased (Fig. 2, lane $2 v s$. lane $1,>$ or $<$, respectively). MeJa induced a synthesis of several unique proteins $(69,60$ and $43 \mathrm{kDa})$ in the HT-stressed zucchini cotyledons, previously identified in zucchini plants as jasmonateinduced polypeptides (JIPs) (ANANIEVA \& ANANIEV, 2003), and strongly increased the intensity of two bands (97.4 and 53kDa, Fig. 2, lane 3), present in the other treatments as well. Additionally, MeJa increased the abundance of polypeptides below $45 \mathrm{kDa}$, including bands at the same relative mass as reserve globulins (20-25kDa) (HARA \& MAtsubara, 1980).

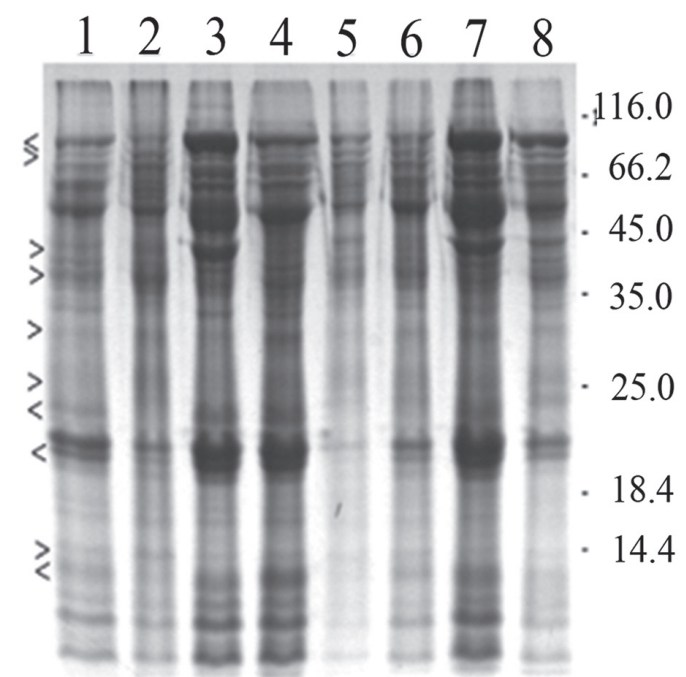

Fig. 2. SDS-PAGE analysis of polypeptide profiles of high temperature-stressed zucchini cotyledons subjected to different pretreatments. Treatments are as follows: lane 1, high temperature $\left(45^{\circ} \mathrm{C}, \mathrm{HT}\right.$, reference sample); lane $2, \mathrm{HT}+$ 4PU-30; lane 3, HT + MeJa; lane 4, $\mathrm{HT}+\mathrm{Cu}^{2+}$; lane 5, HT + 4PU-30 + MeJa; lane 6, HT $+\mathrm{Cu}^{2+}+4 \mathrm{PU}-30$; lane 7, $\mathrm{HT}+$ $\mathrm{Cu}^{2+}+\mathrm{MeJa}$; lane $8, \mathrm{HT}+\mathrm{Cu}^{2+}+4 \mathrm{PU}-30+$ MeJa. Polypeptides with increasing $(>)$ or decreasing $(<)$ intensity due to the 4PU-30 treatment as compared to the reference sample are shown on the left. Protein molecular weight markers (in kDa) are indicated on the right

In contrast to $\mathrm{MeJa}, \mathrm{Cu}^{2+}$ did not induce new protein synthesis, but strongly increased the abundance of almost all soluble polypeptides (Fig. 2, lane 4). When MeJA or/and $\mathrm{Cu}^{2+}$ was applied together with 4PU-30 (Fig. 2, lanes 5, 6 and 8, respectively), the protein profiles of cotyledon tissues were similar to those of 4PU-30 alone treated cotyledons. After the combined treatment with $\mathrm{MeJa}$ and $\mathrm{Cu}^{2+}$ (Fig. 2, lane 7), the profile resembled jasmonate-only treatment. Therefore, $\mathrm{Cu}^{2+}, 4 \mathrm{PU}-30$, and especially MeJa pretreatments can significantly alter gene expression in heat-stressed zucchini cotyledons as evidenced by changes in the number and intensity of polypeptide bands. On the other hand, our results showed differing effects of MeJa, $\mathrm{Cu}^{2+}$ and 4PU-30 on the polypeptide patterns, thus, suggesting different mechanisms of their action.

\section{Activity of antioxidant enzymes}

In the treated zucchini cotyledons, five common SOD isoenzymes (designated SOD1-5, in the order of increasing migration) were resolved on the gel (Fig. 3A). Superoxide dismutase 1 was identified as MnSOD enzyme by its resistance to both cyanide and $\mathrm{H}_{2} \mathrm{O}_{2}$, whereas SOD isoenzymes 2, 3, 4, and 5 were insensitive to inhibition by cyanide and sensitive to inactivation by $\mathrm{H}_{2} \mathrm{O}_{2}$, suggesting that they represented FeSOD activity. No $\mathrm{Cu} / \mathrm{ZnSOD}$ activity band was observed in all the treatments. In Fig. 3, the occurrence of the gel is compared to the densitometric analysis.

The densitometric analysis of the superoxide dismutase zymograms indicated lower enzyme activity in the MeJa-treated and in the $\mathrm{Cu}^{2+}$-treated HTstressed cotyledons as compared to the reference sample (Fig. 3B). MeJa-induced inhibition in the activity of one MnSOD isoform in Ricinus communis leaves has been observed by Dos Santos Soares et al. (2010). In Arabidopsis thaliana, the total SOD activity decreases by $\mathrm{Cu}^{2+}$ excess, at short periods of treatment (MAKSYMIEC \& KRUPA, 2006), but increases after seven days of $\mathrm{Cu}^{2+}$ action (DrĄżKIEWICZ et al., 2004). The observed differences may have resulted from the additional stress factor (HT stress) used in our experiment. Reduction in SOD activity after $\mathrm{Cu}^{2+}$ or MeJa treatments may cause accumulation of superoxide radical $\left(\mathrm{O}_{2} \cdot-\right)$, also observed in A. thaliana (MAKsymiec \& KRUPA, 2006), thereby enhancing oxidative stress. Pretreatment with 4-PU-30 did not significantly affect the total SOD activity in the heat-stressed cotyledons, but enhanced the activity of SOD5. After all the combined treatments, the enzyme activity was higher than in the single (HT, lane 1) and double (HT $+\mathrm{Cu}^{2+}$, lane 4) stress conditions, mainly due to the stimulation of the faster migrating FeSOD isoforms SOD4 and SOD5. 


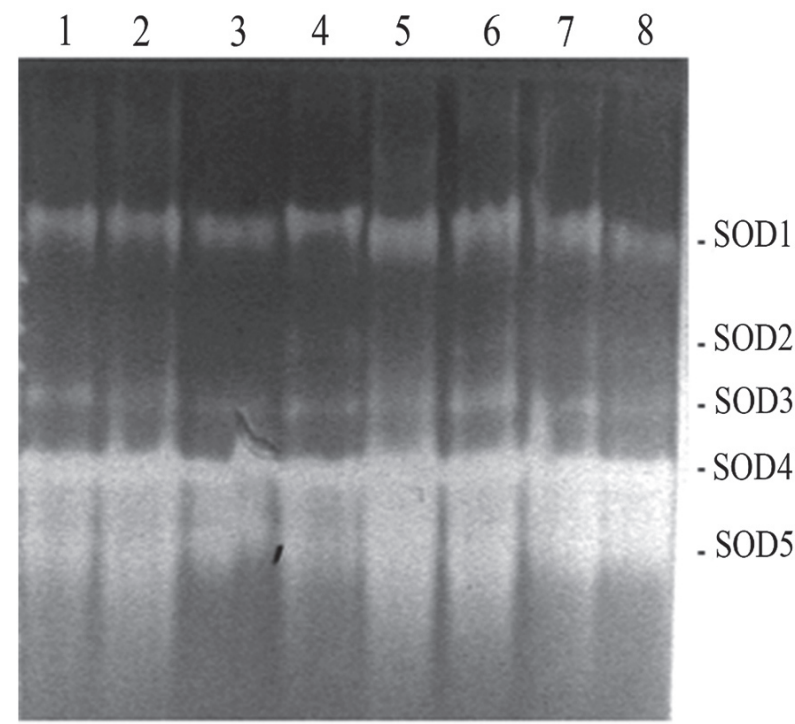

A

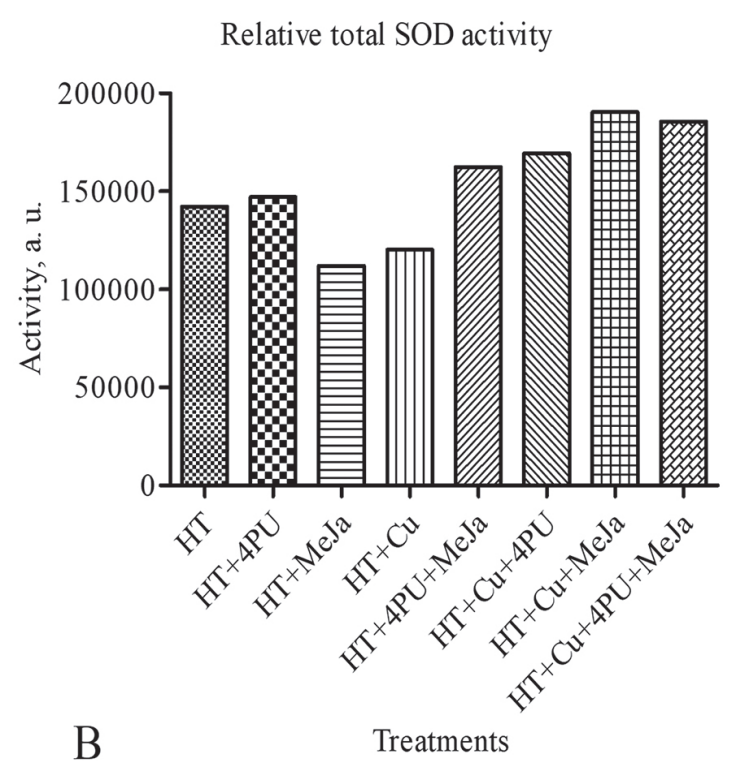

Fig. 3. Effect of different treatments on the pattern and activity of superoxide dismutase (SOD) in zucchini cotyledons. A isoenzyme patterns. Equal amounts of protein $(20 \mu \mathrm{g})$ are loaded per well. The different isoforms of SOD are numbered from cathode to anode. SOD1 represents MnSOD, SOD2, 3, 4 and 5 represent FeSOD activity. The treatments (lanes 1-8) are as in B. B - changes in the relative total SOD activity. The total activity for a particular treatment is expressed as a sum of the values (in arbitrary units, a. u.) for integrated optical density of the respective bands. Quantitative data are from a single representative experiment

On nondenaturing polyacrylamide gels, Px revealed a total of eight molecular forms (Fig. 4A). Isoperoxidase 2 was expressed only in heat-shocked zucchini cotyledons pretreated with 4PU-30 + MeJa. Isoform 4 was induced by MeJa and $\mathrm{Cu}^{2+}$ when applied alone and in combination. Analysis of the gels showed that the total Px activity increased in all the tested variants (Fig. 4B) as compared to the cotyledons treated with HT only (Fig. 4B, lane 1). When MeJa or $\mathrm{Cu}^{2+}$ were applied, the increase was much less pronounced. The highest activity was observed after the 4PU-30 and 4PU-30 $+\mathrm{Cu}^{2+}$ treatments, mainly due to the stimulation of Px1, Px3, and Px8 isoforms. Enhancement in the activity of peroxidases has been observed in many other plants (SYTAR et al., 2013 and refs therein) and seems to be a common response to different stress factors.

Staining for GPx yielded four activity bands. Some weaker bands were visible on the gel (Fig. 5A), which are non-glutathione-specific peroxidase isoforms as evidenced by a comparison of this gel with the patterns of the DAB-specific peroxidase $(\mathrm{Px}$, Fig. 4A). A single faint slowly moving band (GPx2) was observed commonly in all the treatments, but it was more intensive in the only HT- and HT+4PU- 30-treated zucchini cotyledons. The intensity of the second common isoform, GPx3, did not appear to change significantly in the MeJa or $\mathrm{Cu}^{2+}$ pretreated heat-stressed cotyledons. In contrast, 4PU-30 alone and in combination significantly elevated its intensity. Furthermore, 4PU-30 promoted the occurrence of a new glutathione peroxidase form - GPx4. A very slowly moving band of GPx 1 was visible only in the sample under double stress conditions (Fig. 4, lane 4). In general, $\mathrm{Cu}^{2+}$ and especially MeJa repressed the total GPx activity (Fig. 4B), whereas 4PU-30 had a strong stimulatory effect, resulting from the activation of GPx3 and induction of GPx4 isoforms. The low activity of GPx in the MeJa or $\mathrm{Cu}^{2+}$ pretreated heat-stressed zucchini cotyledons might be due to the low substrate (GSH) level under these conditions. In A. thaliana, exogenously applied MeJa diminishes GSH accumulation after $\mathrm{Cu}^{2+}$ supply (MAKSYMIEC et al., 2007). However, upon the combined stress, the treatments with MeJa and especially 4PU-30 stimulated the total GPx activity.

Gels stained for GR activity revealed two well-resolved bands (GR1 and GR2) in the cotyledon extracts following all the treatments (Fig. 6A). Pretreatment with 4PU-30 did not affect GR activity in the HT- 


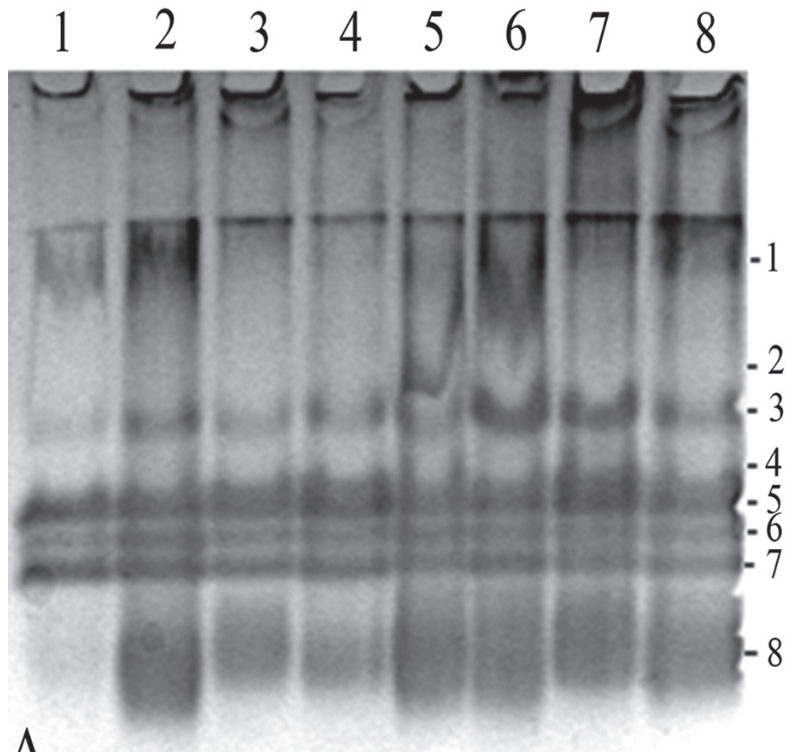

A

Fig. 4. Effect of different treatments on the pattern and activity of peroxidase (Px) in zucchini cotyledons. A - isoenzyme patterns. Anodically migrating peroxidase isoforms are visualized by staining in $\mathrm{DAB} / \mathrm{H}_{2} \mathrm{O}_{2}$ and numbered in the order of increasing electrophoretic mobility. The samples loaded on the gel (lanes 1-8) are as in $\mathrm{B}$. $\mathrm{B}-$ changes in the relative total Px activity

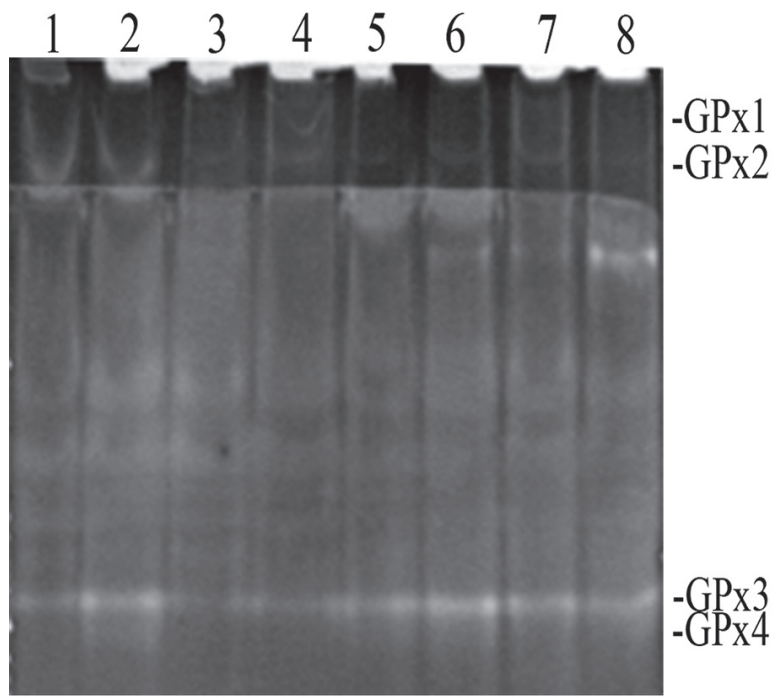

A

Fig. 5. Effect of different treatments on the pattern and activity of glutathione peroxidase (GPx) in zucchini cotyledons. A - isoenzyme patterns, showing position and changes in the number and intensity of enzyme isoforms in zucchini cotyledons treated as in B. B - changes in the relative total GPx activity

exposed cotyledons (Fig. 6B). In contrast, $\mathrm{Cu}^{2+}$ and especially MeJa inhibited this enzyme. The decrease in total GR activity appeared to result from a decline in both the GR1 and GR2 isoforms. Suppressed activity of GR under $\mathrm{Cu}^{2+}$ stress has also been registered in other plant species (SYTAR et al., 2013 and literature

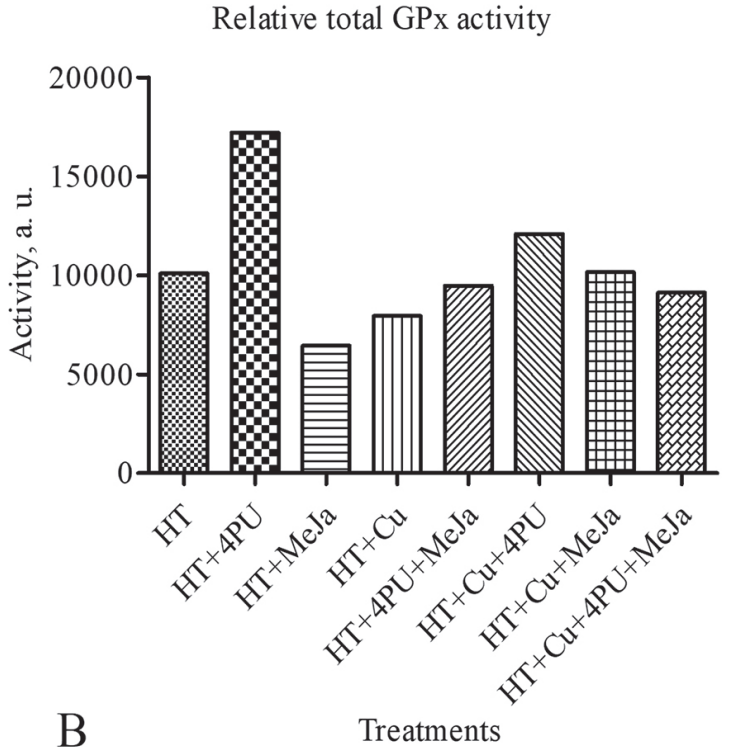




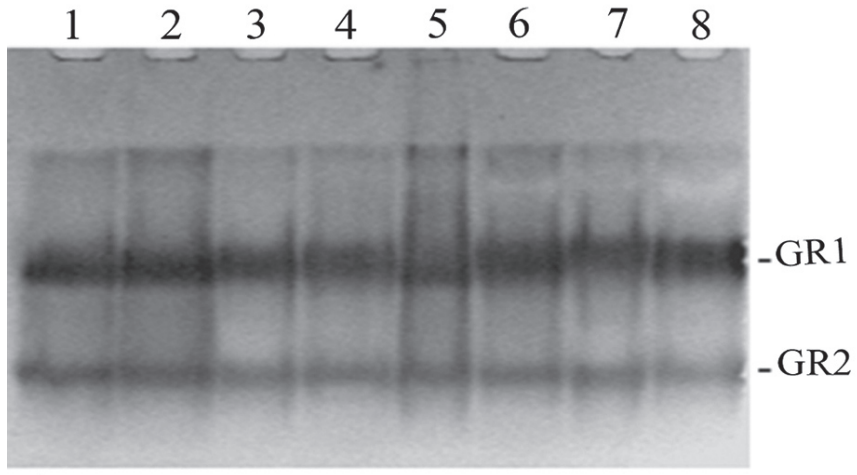

A

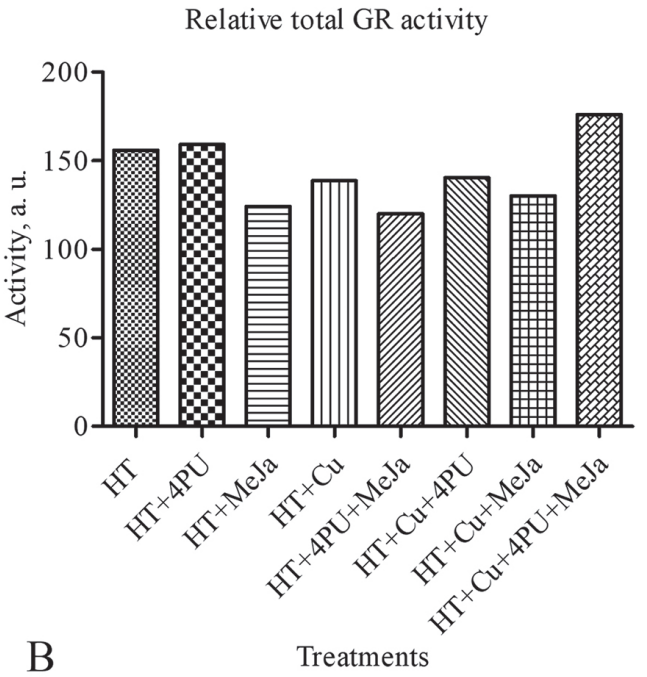

Fig. 6. Effect of different treatments on the pattern and activity of glutathione reductase (GR) in zucchini cotyledons. A - isoenzyme patterns; B - relative total GR activity; the treatments in A are as in B

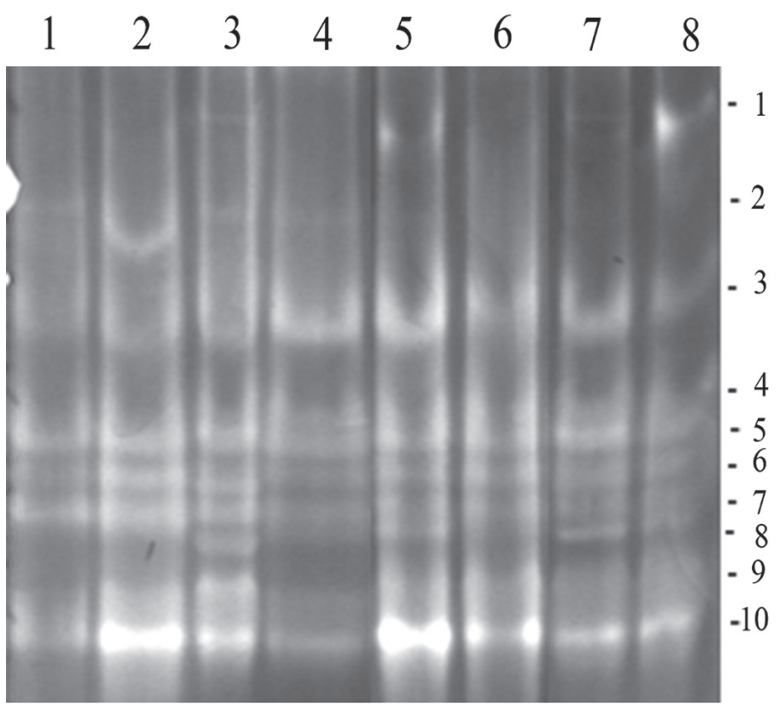

A

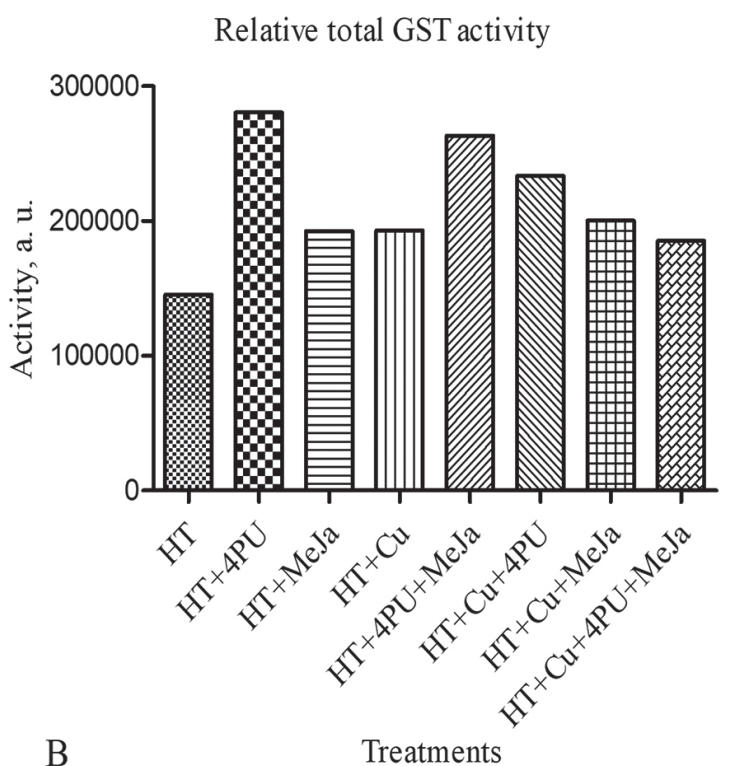

Fig. 7. Effect of different treatments on the pattern and activity of glutathione-S-transferase (GST) in zucchini cotyledons. A isoenzyme patterns; B - relative total GST activity; the treatments in A are as in B

applied alone, 4PU-30 and MeJa were not able to improve the total GR activity of zucchini cotyledons subjected to double stress conditions, but their coadministration resulted in a marked increase in GR1 intensity and, thus, in the highest total enzyme activity (Fig. 6). In tolerant varieties of rice, the increase in GR activity has been found to play an important role in heat stress resistance (NAHAKPAM \& SHAH, 2011).

Plant GSTs are a ubiquitous family of multifunctional enzymes, with a largely known role in xenobi- otics detoxification (EDwards \& Dixon, 2005). Observations that mRNAs encoding proteins with GST activity accumulate following treatment with plant hormones (Moons, 2005; SHI et al., 2014), heavy metals (CHAKRABARTY et al., 2009) and pathogen infection (LiEBERHERr et al., 2003), however, suggest that the respective enzymes play an important role in the response of plants to abiotic and biotic stress. Moreover, overexpression or heterologous expression of GSTs was reported to improve plant tolerance to salt (QI et 
al., 2010), drought (GEORGE et al., 2010) and heavy metal, cold and osmotic stress (KuMAr et al., 2013).

Seven bands of GST isoforms $(2,3,5,6,7,9$, 10) were detected in the only heat-stressed zucchini cotyledons (Fig. 7A). Under the influence of 4-PU30 , no new isoforms appeared, but the intensity of the existing isoforms was enhanced (Fig. 7A, lane 2). MeJa exposure induced the occurrence of GST1, GST4, and GST8. The isoforms GST4 and GST8 were visible also in the $\mathrm{Cu}^{2+}$ treated heat-stressed cotyledons. Despite the almost equal total GST activity, the intensity of the individual isoforms varied considerably in the last two treatments (Fig. 7A, lanes 3 and 4). Applied alone, MeJa and $\mathrm{Cu}^{2+}$ enhanced the total GST activity of the heat-stressed cotyledons, but to a lesser extent than 4PU-30, where the activity was the highest among all the treatments (Fig. 7B). In the combined 4PU-30 $+\mathrm{Cu}^{2+}$ treatments, the effect of MeJa was preponderant in the isoform patterns, while 4PU-30 dominated with respect to enzyme activity. The increase in GST activity may be a defense response of the zucchini cotyledons, expressed through a disposal of the accumulated during the stress endogenous toxic compounds.

\section{CONCLUSIONS}

The obtained results indicated that the $\mathrm{Cu}^{2+}$ exposure prior to heat treatment presented new harsher conditions for the growth and survival of zucchini plants, probably by increasing the level of oxidative stress. The inhibition of growth by $\mathrm{Cu}^{2+}$ was accompanied by a marked decrease in SOD, GPx and GR activities. Exogenous application of phenylurea cytokinin stimulated the growth of stressed zucchini cotyledons. Perhaps, the coordinated action of 4PU-30induced activity of Px, GPx, GST and SOD5, and the previously observed stimulatory effect of cytokinins on the synthesis of some flavones (STOYNOVA-BAKALOVA et al., 2009) helped the plants to successfully overcome the stress caused by HT alone or in combination with excess $\mathrm{Cu}^{2+}$. MeJa pretreatment improved the growth of the heat-stressed cotyledons, and to a lesser extent of the $\mathrm{HT}+\mathrm{Cu}^{2+}$-stressed ones. Because all the antioxidant enzyme activity levels were similar in the case of MeJa and $\mathrm{Cu}^{2+}$ applied separately prior to the HT stress, the stimulating effect of MeJa on the growth was probably realized through modulation of the activity of individual enzyme isoforms. The role of the jasmonates-induced proteins (JAPs), which are known to be stress protectors, may also be assumed. Alterations in the activity of a particular isoform of any antioxidant enzyme can be more beneficial for antioxidant metabolism than changes in the total activity, due to the action of that isoform in the specific cellular compartment. In the zucchini seedlings, the changes in the total antioxidant enzyme activity and the activity of individual isoenzymes participated in stress responses as well as in the protective effects.

\section{ACKNOWLEDGEMENTS}

The authors sincerely thank Waldemar Maksymiec, from the Maria Curie-Skłodowska University, Lublin, Poland, for language review.

\section{REFERENCES}

Ananieva K.I., Ananiev E.D., 2003: Phenylmethylsulphonyl fluoride inhibits the formation of jasmonates-induced proteins in cotyledons of Cucurbita pepo (zucchini). - Biologia Plantarum, 46: 357-362.

Anderson M.D., Prasad T.K., Stewart C.R., 1995: Changes in isozyme profiles of catalase, peroxidase, and glutathione reductase during acclimation to chilling in mesocotyls of maize seedlings. - Plant Physiology, 109: 1247-1257.

Ara N., Nakkanong K., Lv W., Yang J., Hu Z., Zhang M., 2013: Antioxidant enzymatic activities and gene expression associated with heat tolerance in the stems and roots of two cucurbit species ("Cucurbita maxima" and "Cucurbita moschata") and their interspecific inbred line "Maxchata". - International Journal of Molecular Sciences, 14: 24008-24028.

Azevedo R.A., Alas R.M., Smith R.J., Lea P.J., 1998: Response of antioxidant enzymes to transfer from elevated carbon dioxide to air and ozone fumigation, in the leaves and roots of wild-type and catalase-deficient mutant of barley. - Physiologia Plantarum, 104: 280-292.

BRADFORD M., 1976: A rapid and sensitive method for the quantification of microgram quantities of protein utilizing the principle of protein-dye binding. - Analytical Biochemistry, 72: 248-254. 
Candan N., Tarhan L., 2003: The correlation between antioxidant enzyme activities and lipid peroxidation levels in Mentha pulegium organs grown in $\mathrm{Ca}^{2+}, \mathrm{Mg}^{2+}, \mathrm{Cu}^{2+}, \mathrm{Zn}^{2+}$ and $\mathrm{Mn}^{2+}$ stress conditions. - Plant Science, 165: 769-776.

Chakrabarty D., Trivedi P.K., Misra P., Tiwari M., Shri M., Shukla D., Kumar S., Rai A., PanDEY A., Nigam D., 2009: Comparative transcriptome analysis of arsenate and arsenite stresses in rice seedlings. - Chemosphere, 74: 688-702.

Chen P., Yu S., Zhan Y., Kang X.L., 2006: Effects of jasmonate acid on thermotolerance of grape seedlings. - Journal of Shihezi University (Natural Science), 24: 87-91.

Clarke S.M., Cristescu S.M., Miersch O., HarRen F.J.M., Wasternack C., Mur L.A.J., 2009: Jasmonates act with salicylic acid to confer basal thermotolerance in Arabidopsis thaliana. - New Phytologist, 182: 175-187.

Dos Santos Soares A.M., De Souza T.F., Jacinto T., Machado O.L.T., 2010: Effect of methyl jasmonate on antioxidative enzyme activities and on the contents of ROS and $\mathrm{H}_{2} \mathrm{O}_{2}$ in Ricinus communis leaves. - Brazilian Journal of Plant Physiology, 22(3): 151-158.

Drążkiewicz M., Skotrzyniska-Polit E., Krupa Z., 2004: Copper-induced oxidative stress and antioxidant defence in Arabidopsis thaliana. - BioMetals, 17: 379-387.

Edwards R., Dixon D.P., 2005: Plant glutathione transferases. - Methods in Enzymology, 401: 169-186.

George S., Venkataraman G., Parida A., 2010: A chloroplast-localized and auxin-induced glutathione S-transferase from phreatophyte Prosopis juliflora confer drought tolerance on tobacco. - Journal of Plant Physiology, 167: 311-318.

Gigova L., Ivanova N., Gacheva G., Andreeva R., FuRNADZHIEVA S., 2012: Response of Trachydiscus minutus (Xanthophyceae) to temperature and light. - Journal of Phycology, 48(1): 85-93.

Hara I., Matsubara H., 1980: Pumpkin (Cucurbita sp.) seed globulin VI. Proteolytic activities appearing in germinating cotyledons. - Plant and Cell Physiology, 21(2): 233-245.

Hasanuzzaman M., Nahar K., Alam Md.M., RoyCHOWdhury R., Fujita M., 2013: Physiological, biochemical, and molecular mechanisms of heat stress tolerance in plants. - International Journal of Molecular Sciences, 14: 9643-9684.

Kumar A., Prasad M.N.V., Sytar O., 2012: Lead toxicity, defense strategies and associated indicative biomarkers in Thalinum triangulare grown hydroponically. - Chemosphere, 89: 1056-1165.

Kumar S., Asif M.H., Chakrabarty D., TriPAthi R.D., Dubey R.S., Trivedi P.K., 2013: Expression of a rice Lambda class of glutathione S-transferase, OsGSTL2, in Arabidopsis provides tolerance to heavy metal and other abiotic stresses. - Journal of Hazardous Materials, 248-249: 228-237.

Lieberherr D., Wagner U., Dubuis P.-H., MéTRAUX J.-P., MAUCH F., 2003: The rapid induction of glutathione $S$-transferases AtGSTF2 and AtGSTF6 by avirulent Pseudomonas syringae is the result of combined salicylic acid and ethylene signaling. Plant and Cell Physiology, 44: 750-757.

Lin C.L., Chen H.J., Hou W.C., 2002: Activity staining of glutathione peroxidase after electrophoresis on either native or sodium dodecylsulfate polyacrylamide gels. - Electrophoresis, 23: 513-516.

MaKsymiec W., Krupa Z., 2006: The effects of short term exposition to $\mathrm{Cd}$, excess $\mathrm{Cu}$ ions and jasmonate on oxidative stress appearing in Arabidopsis thaliana. - Environmental and Experimental Botany, 57: 187-194.

Maksymiec W., Wóscik M., Krupa Z., 2007: Variation in oxidative stress and photochemical activity in Arabidopsis thaliana leaves subjected to excess copper and cadmium after jasmonate or ascorbate supply. - Chemosphere, 66: 421-427.

Moons A., 2005: Regulatory and functional interactions of plant growth regulators and plant glutathione $S$-transferases (GSTs). - Vitamins \& Hormones, 72: 155-202.

NahaKpam S., Shah K., 2011: Expression of key antioxidant enzymes under combined effect of heat and cadmium toxicity in growing rice seedlings. Plant Growth Regulation, 63: 23-35.

Okajima T., Tanabe T., Yasuda T., 1993: Nonurea sodium dodecyl sulfate polyacrylamide gel electrophoresis with high molarity buffers for the separation of proteins and peptides. - Analytical Biochemistry, 211: 293-300.

Qi Y.C., Liu W.Q., Qiu L.Y., Zhang S.M., Ma L., ZHANG H., 2010: Overexpression of glutathione 
S-transferase gene increases salt tolerance of Arabidopsis. - Russian Journal of Plant Physiology, 57: 233-240.

Per T.S., Khan M.I.R., Anjum N.A., Masood A., Hussain S.J., Khan N.A., 2018: Jasmonates in plants under abiotic stresses: crosstalk with other phytohormones matters. - Environmental and Experimental Botany, 145: 104-120.

Ricci G., Bello M.L., Caccuri A.M., Galiazzo F., FEDERICI G., 1984: Detection of glutathione transferase activity on polyacrylamide gels. - Analytical Biochemistry, 143: 226-230.

Rojas-Beltran J.A., Dejaeghere F., Abd Alla Kotb M., Du JARDIN P., 2000: Expression and activity of antioxidant enzymes during potato tuber dormancy. - Potato Research, 43: 383-393.

Sergiev I.G., Alexieva V.S., Ivanov S.V., MosKova I.I., Karanov E.N., 2006: The phenylurea cytokinin 4PU-30 protects maize plants against glyphosate action. - Pesticide Biochemistry and Physiology, 85: 139-146.

Sergiev I., Todorova D., Shopova E., Katerova Z., JANKAUSKIENĖ J., JuRKONIENĖ S., 2017: Auxin-like compounds act as protectors against UV-B irradiation in garden pea plants. - Botanica Lithuanica, 23(2): 79-88.

Sharma P., Jha A.B., Dubey R.S., Pessarakli M., 2012: Reactive oxygen species, oxidative damage, and antioxidative defense mechanism in plants under stressful conditions. - Journal of Botany, 217037: 1-26.

Shi H-Y., Li Z-H., Zhang Y-X., Chen L., Xiang D-Y., ZHANG Y-F., 2014: Two pear glutathione S-transferases genes are regulated during fruit development and involved in response to salicylic acid, auxin, and glucose signaling. - PLoS ONE, 9(2): e89926. doi:10.1371/journal.pone.0089926.

Singh I., Sнан K., 2014: Exogenous application of methyl jasmonate lowers the effect of cadmiuminduced oxidative injury in rice seedlings. - Phytochemistry, 108: 57-66.

Stoynova-BaKalova E., Petrov P.I., Gigova L., BASKIN T.I., 2008: Differential effects of methyl jasmonate on growth and division of etiolated zucchini cotyledons. - Plant Biology, 10: 476-484.

Stoynova-BaKalova E., Nikolova M., MaksyMIEC W., 2009: Effects of $\mathrm{Cu}^{2+}$, cytokinins and jasmonates on content of two flavonols identified in zucchini cotyledons. - Acta Biologica Cracoviensia Series Botanica, 51(1): 79-84.

Suzuki N., Mittler R., 2006: Reactive oxygen species and temperature stresses: a delicate balance between signaling and destruction. - Physiologia Plantarum, 126: 45-51.

Sytar O., Kumar A., Latowski D., Kuczyńska P., StrzaŁka K., Prasa M.N.V., 2013: Heavy metal-induced oxidative damage, defence reactions, and detoxification mechanisms in plants. - Acta Physiologiae Plantarum, 35: 985-999.

Sytar O., Kumari P., Yadav S., Brestic M., Rastogi A., 2019: Phytohormone Priming: Regulator for Heavy Metal Stress in Plants. - Journal of Plant Growth Regulation, 38: 739-752.

Todorov D., Alexieva V., Karanov E., 1998: Effect of putrescine, 4-PU-30, and abscisic acid on maize plants grown under normal, drought, and rewatering conditions. - Journal of Plant Growth Regulation, 17: 197-203.

Verma V., Ravindran P., Kumar P.P., 2016: Plant hormone-mediated regulation of stress responses. - BMC Plant Biology, 16: 86.

Wang S.H., Yang Z.M., Yang H., Lu B., Li S.Q., LU Y.P., 2004: Copper induced stress and antioxidative responses in roots of Brassica junicea L. - Botanical Bulletin of Academia Sinica, 45: 203-212.

Xu S., Li J., Zhang X., Wei H., Cui L., 2006: Effects of heat acclimation pretreatment on changes of membrane lipid peroxidation, antioxidant metabolites, and ultrastructure of chloroplasts in two cool-season turfgrass species under heat stress. Environmental and Experimental Botany, 56: 274-285.

Yordanov I., Tsonev T., Goltsev V., MerakchisKa-Nikolova V.M., Georgieva K., 1997: Gas exchange and chlorophyll fluorescence during water and high temperature stresses and recovery. Probable protective effect of urea cytokinin 4-PU-30. - Photosynthetica, 33: 423-431.

YRUELA I., 2009: Copper in plants: acquisition, transport and interactions. - Functional Plant Biology, 36: 409-430.

Zhu Y., Zhu G., Guo Q., Zhu Z., Wang C.H., Liu Z., 2013: A comparative proteomic analysis of Pinellia ternata leaves exposed to heat stress. International Journal of Molecular Sciences, 14: 20614-20634. 


\title{
KAI KURIŲ AUGALŲ HORMONŲ POVEIKIS CUKINIJOS SKILČIALAPIAMS AUKŠTOS TEMPERATŪROS IR VARIO PERTEKLIAUS STRESO ITTAKOJE
}

\author{
Ekaterina Stoynova-Bakalova, Natalia Ivanova, Dimitar BaKalov, Liliana Gigova
}

\section{Santrauka}

Darbo užduotis buvo ištirti galimą teigiamą metiljasmonato (MeJa) ir fenilkarbamido citokinino (4PU-30) poveiki cukinijų (Cucurbita pepo) skilčialapiams aukštos temperatūros (AT) bei kombinuoto AT ir vario $\left(\mathrm{Cu}^{2+}\right)$ pertekliaus sukelto streso įtakoje. Lyginant šių stresinių faktorių įtaką buvo nustatyta, kad padidintas $\mathrm{Cu}^{2+}$ kiekis, priešingai nei AT stresas, slopino skilčialapių augimą, sumažino superoksido dismutazès (SOD), glutationo peroksidazès (GPx) ir glutationo reduktazès (GR) aktyvumą, padidino glutationo-S-transferazès (GST) ir peroksidazès (Px) bendrą aktyvumą ir indukavo naujas fermentų izoformas (GST4, GST8 ir Px4). MeJa padidino augalų, paveiktų kombinuotu stresu SOD, GPx ir Px aktyvumą bei stimuliavo GST8, GST9, GST10, SOD5, Px3 ir
Px8 izofermerus. Citokininas 4PU-30, be SOD, GPx ir Px, padidino bendrą GST aktyvumą, išryškino Px1 ir GR1 bei turèjo stimuliuojantị poveiki SOD5, Px3, GPx3, GST9 ir GST10 aktyvumui. Varis, 4PU-30 ir MeJa specifiškai pakeite tirpių polipeptidų gausą ir struktūrą. Skilčialapių, paveiktų AT, augimą stimuliavo MeJa ir 4PU-30, naudoti atskirai arba kartu. Didesni atstatomaji poveiki streso sukeltam augimo slopinimui turejjo 4PU-30, lyginant su MeJa. Tyrimų duomenys parode, kad tiek MeJa, tiek 4PU-30 gali apsaugoti cukinijų augalus nuo aukštos temperatūros ir kombinuoto aukštos temperatūros bei vario sukelto streso. Didesnis apsauginis 4PU-30 poveikis buvo susijęs su genų raiškos pokyčiais, bendru antioksidantinių fermentų ir atskirų jų izoformų aktyvumu. 